\title{
Introvert dan Ekstrovert
}

Mungkin kalian pernah mendengar tentang kepribadian Introvert dan Ekstrovert. Seperti yang sering kita dengar dan kita baca di media sosial tentang kepribadian Introvert dan Ekstrovert.

Yang menyatakan bahwa

- Introvert itu sebagai yang pendengar yang baik tapi juga pemalu, temannya sedikit dan kemampuan sosial nya kurang bagus atau suka disebut anti sosial.

- Ekstrovert itu sebagai pribadi yang jago ngomong, gampang bersosialisasi, punya banyang teman dan bakal lebih sukses dari Introvert.

Sebetulnya benar gak sih seperti itu ? Nah sebenarnya darimana sih kepribadian ini berasal ?

Konsep Introvert dan ekstovert dipopulerkan oleh salah satu psikolog terkenal bernama Carl Jung, dia membuat teori mengenai elemen-elemen kepribadian yang mendefinisikan bahwa : Introvert atau introversion sebagai kecenderungan seseorang untuk mendapatkan energi dari dalam diri dan berfokus sama hal-hal yang ada dalam diri mereka. Misalnya dengan menyendiri di kamar dan lain sebagainya. Sebaliknya ekstrovert atau extraversion adalah kecenderungan seseorang untuk berfokus sama hal-hal di luar dirinya dan mendapatkan energi dari hal-hal tersebut misalnya interaksi sama orang-orang dan lain sebagainya.

Misalnya seorang ekstrovert itu mengasosiasikan rasa senang dengan lingkungan mereka dan ekstrovert juga bisa merespon terhadap berbagai hal dengan lebih cepat jadinya mereka membutuhkan banyak stimulasi di lingkungan misalnya dari berinteraksi dengan orang lain ngobrol nongkrong dan sebagainya. Ini jauh beda dengan introvert yang memang biasanya mengasosiasikan rasa senang dengan faktor dalam diri. Introvert juga merespon terhadap berbagai hal dengan lebih lambat tapi dengan dipikirkan secara lebih dalam sehingga stimulasi dari lingkungan itu lebih mudah bikin lelah energinya.

Dari penjelasan tersebut bisa disimpulkan bahwa sebenarnya kedua konsep introvert or extrovert itu sebenarnya membahas cara orang mendapatkan energi dan hal inilah yang menyebabkan adanya perbedaan antara ekstrovert dan introvert. Sayangnya memang banyak miskonsepsi dikalangan kita. 


\section{Contohnya :}

Salah satu miskonsepsi nya bahwa ada yang menganggap bahwa introvert tuh lebih pintar daripada ekstrovert dan ekstrovert nggak lebih pintar dari introvert. Ekstrovert itu jago ngomong sedangkan introvert itu pendiam. Padahal gak ada kepribadian yang secara mutlak lebih baik atau lebih buruk dari kepribadian lainnya. Pasti ada plus minus nya. Kecenderungan itu hanyalah sebuah presensi yang disebabkan oleh cara masing2 tipe kepribadian mendapatkan energi bukan menceritakan kepintaran.

Contoh :

Kecenderungan ekstrovert yang memilih menyelesaikan masalah dengan cara berdiskusi. Kecenderungan introvert untuk berkontemplasi sendiri dapat membantu mereka menemukan solusi yang kreatif.

Menurut penelitian ternyata ada 4 tipe introvert

\section{Introvert sosial}

Tipe ini merupakan tipe yang paling terbuka. Tidak begitu malu dan cemas dengan lingkungan sosial, tapi mereka akan terkuras secara emosional kalau mereka berada disana dalam jangka waktu yang lama. Introvert sosial ini suka menghabiskan waktu sendirian mereka di waktu-waktu tertentu tapi mereka dapat andalkan dan mereka cenderung menjadi yang paling sosial. Dan ketika mereka berada di kelompok orang lain yang tidak paham tentang struktur sosial mungkin akan berasumsi bahwa mereka itu sebagai seorang ekstrovert karena mereka melihat tidak ada bedanya antara introvert sosial dan seorang ekstrovert. Introver sosial ini tidak akan mau banyak berbagi tentang mereka selain dengan teman dekat mereka.

\section{Introvert pemikir}

Kepribadian ini banyak menghabiskan waktu di dalam kepala mereka alias mereka suka memikirkan berbagai macam hal. Dilansir oleh the privat terapis klinik, introvert pemikir akan mengolah semua yang mereka dengar dan mereka lihat. Tidak jarang kamu akan menemukan mereka melamun, padahal saat itu mereka sedang bermain-main dengan imajinasinya yang sangat luas. Introvert pemikir tidak keberatan untuk bersosialisasi tetapi mereka jarang 
melakukannya karena mereka lebih memilih untuk menghabiskan waktunya sendiri. Bukan hanya itu, orang lain sering sulit memahami para Introvert pemikir ini sebab mereka memiliki jalan pikiran yang unik dan tidak suka menjelaskannya kepada orang lain, orang yang introvert pemikir merupakan tipe orang yang selalu mawas diri karena itu mereka lebih selaras dengan perasaan mereka daripada kebanyakan.

\section{Introvert yang cemas}

Introvert yang cemas mendambakan kesendirian bahkan ketika mereka sedang bersama teman-teman dekat mereka, mereka sangat tidak nyaman dalam situasi sosial baru dan mereka selalu mencoba terus-menerus menganalisa dan merenungkan perilaku mereka setiap kali mereka berada di depan umum. Tanda sebagai seorang introvert dan cemas dan itu harus dibutuhkan perhatian dari seorang profesional.

\section{Introvert terkendali}

Mereka merasa tidak nyaman jika mereka harus tergesa-gesa dalam situasi tertentu terutama dalam situasi sosial. Introvert yang terkendali adalah tipe yang pendiam, bijaksana dan tidak menyukai perubahan. Mereka akan datang di suatu acara jika memang sudah direncanakan dari jauh-jauh hari sebelum tetapi mereka sebenarnya lebih suka memilih bersantai diri menonton acara favorit. Introvert yang terkendali menemukan kenyamanan dalam rutinitas mereka dan mungkin juga mereka sulit untuk menggerakkan pikiran dan tubuh mereka untuk segera bangun. Mereka berkembang dengan rutinitas mereka dan menghargai banyak peringatan yang mereka terima sebelumnya. Kalau kamu berpikir bahwa kamu sebagai seorang introvert tapi tidak ada satupun dari 4 diatas yang kamu dapatkan, kamu mungkin sebagai seorang ambivert atau lebih dekat ke sisi ekstrovert.

Kalau kamu seorang introvert yang mana dari keempat introvert ini yang berhubungan dengan kamu?

Tokoh dunia sukses yang punya kepribadian Introvert

\section{Albert Einstein}


Ilmuwan Fisika dunia ini juga seorang introvert loh. Kata-kata Einstein yang terkenal adalah "the monotony and solitude of a quiet life stimulates the creative minds." Bagaimanapun, dalam keheningannya itulah kita mendapat warisan Teori Relativitas dan Kuantum Cahaya - sebagian dari peninggalan berharga Einstein.

\section{Bill Gates}

Perusahaan teknologi besar dunia ini dilahirkan sebagai seorang introvert yang pendiam dan suka membaca buku.

Menurut Gates, "... introverts can do quite well. If you're clever you can learn to get the benefits of being an introvert, which might be, say, being willing to go off for a few days and think about a tough problem, read everything you can, push yourself very hard to think out on the edge of that area."

\section{J.K. Rowling}

Sorang penulis novel Harry Potter

Dan masih banyak lagi tokoh lainnya.

Jadi jika ada yang masih memiliki mindset bahwa ekstrovert akan lebih sukses dari pada ekstrovert dengan sederet kelebihan seperti mudah bergaul dan jago publick speaking, maka hal itu salah. Karena seperti dijelaskan diatas bahwa yang membedakan antara 2 kepribadiannya itu ada pada cara mendapatkan energi. Selebihnya mengenai skill dan lain sebagainya itu bisa dipelajari. 